\title{
Antibiotics Efficacy on In Vitro Growth Parameters of Important Potato Cultivars
}

\author{
Tanuja Buckseth $^{1 *}$, R. K. Singh ${ }^{1}$, Sumita Sharma ${ }^{1}$, Ashwani K. Sharma ${ }^{2}$, \\ Vaishali Moudgil ${ }^{1}$ and Aastha Saraswati ${ }^{1}$ \\ ${ }^{1}$ ICAR-Central Potato Research Institute, Shimla- 171001 (HP), India \\ ${ }^{2}$ ICAR-Central Potato Research Station, Kufri-171012 (HP), India \\ *Corresponding author
}

\begin{tabular}{|c|c|}
\hline & A B S T R A $\mathbf{T}$ \\
\hline $\begin{array}{l}\text { Microplants, } \\
\text { Antibiotics, } \\
\text { Amphotericin-b, } \\
\text { Antimycotic, } \\
\text { Varieties, Potato. }\end{array}$ & \multirow{3}{*}{$\begin{array}{l}\text { The use of plant tissue culture as a routine method of potato seed production would be } \\
\text { costly but these techniques can be used to eliminate the pathogens, produce required initial } \\
\text { material and then, use another efficient and cheaper system to rapidly produce high quality } \\
\text { seed tubers for commercial production. Considering this, the liquid formulation of } \\
\text { antimycotic } 100 \mathrm{x} \text {, and amphotericin-B } 250 \mu \mathrm{g} / \mathrm{ml} \text { of PAA make was used. These test } \\
\text { antibiotics were added aseptically at various concentrations }(0.5 \%, 1 \%, 1.5 \% \text {, and } 2 \%) \text { in } \\
\text { the sterilized MS medium culture tubes to find out contamination free, vigorous in-vitro } \\
\text { growth of the microplants. It was observed that amphotericin-b at lower conc. i.e., } 0.5 \% \\
\text { and } 1 \% \text { could be incorporated in the micro propagation medium of potato to minimize } \\
\text { fungal contaminations as well as for improving the microplants vigour. However, all the } \\
\text { tested antimycotic concentrations had negative effects on almost all the morphological } \\
\text { characters studied, which need further investigation with lower concentrations. }\end{array}$} \\
\hline Article Info & \\
\hline $\begin{array}{l}\text { Accepted: } \\
\text { 10 September } 2017 \\
\text { Available Online: } \\
10 \text { November } 2017\end{array}$ & \\
\hline
\end{tabular}

\section{Introduction}

Seed constitutes a major and important input in potato (Solanum tuberosum L.) cultivation. On account of vegetative propagation, the requirement of seed potatoes (tubers) is voluminous and accounts for 40-50\% of the total production (Buckseth et al., 2016). Potato productivity in India is low in comparison to developed countries due to the non-availability of quality seed in required amounts. Seed potato production involving micro-propagation (tissue culture) techniques can overcome many of the problems associated with the conventional multiplication system (Buckseth et al., 2017). The everlasting shortage of seed potatoes in most of the potato growing nations can be overcome through micro-propagation techniques on account of faster rate of multiplication (Singh et al., 2016). Besides, rapid multiplication, disease freedom on account of multiplication of disease free mother stocks under controlled conditions followed by reduced number of field exposures as compared to conventional multiplication system is an added advantage of seed potato production through tissue culture techniques (Venkataslam et al., 2017). Due to these numerous advantages, the new system of seed potato production involving micro-propagation is finding favour among 
the seed potato entrepreneurs. Tissue culture based hi-tech seed potato production is spreading very fast in the country. Micropropagation at faster rate and free from cultural contamination is an integral component for the success of in-vitro mass multiplication of potato. Plant tissue cultures can be contaminated by different microorganisms, which include bacteria and fungi. They can reduce the productivity and can completely prevent their cultivation (Sen et al., 2013). Fungal and bacterial contamination can also reduce the growth rate, retard rooting, and can even cause plant death (Leifert and Waites, 1992). Tissue cultures can become contaminated at any stage of the tissue culturing process (Leifert, 2000). The most difficult to control are endogenous bacteria, which do not cause any visible symptoms in the contaminated culture. Successful tissue culture protocols start with effective sterilization process. Though, surface sterilization eliminates the exophytic microbes (George, 1993) but, endophytic contamination can only be eradicated by antibiotic therapy (Jung, 2003). Antifungal agents like amphotericin B and antimycotic are one of the polyene antibiotics and is widely used for the treatment of systemic fungal infections. In plants grown in vitro, the presence of microorganisms with the culture medium often is associated to contamination, thus their unwanted presence, since one of the objectives of this technique is precisely to obtain axenic plants, or entirely free microorganisms (Leifert and Cassells, 2001; Harshal et al., 2014).

Therefore, a study was conducted to investigate the effect of these antifungal agents (Amphotericin-B and Antimycotic) for different concentrations for four varieties (Kufri Jyoti, Kufri Sadabahar, Kufri Lauvkar and Kufri Sindhuri) to find out contamination free, vigorous in-vitro growth of the microplant in MS media.

\section{Materials and Methods}

The research was carried out at ICAR-Central Potato Research Institute, Shimla with four important varieties of potato viz., Kufri Jyoti, Kufri Sadabahar, Kufri Lauvkar and Kufri Sindhuri. The broad spectrum antibiotics in liquid commercial formulation of PAA (Phenyl acetic acid) make was used in the experiment. The liquid formulation of antimycotic 100x, and amphotericin-B 250 $\mu \mathrm{g} / \mathrm{ml}$ of PAA make was used. These test antibiotics were added aseptically at various concentrations $(0.5 \%, 1 \%, 1.5 \%$, and $2 \%)$ in the sterilized MS medium culture tubes (Murashige and Skoog, 1962). Three single node pieces of explants were vertically inserted in MS culture medium per tubes at equilateral distance (Naik et al., 2007). The culture tubes were kept for 21days in culture room with 16 hours light (irradiance of 60 $\mu \mathrm{mol} / \mathrm{m}^{2} / \mathrm{s}$ ) and 8 hours dark photoperiodism at $22 \pm 1{ }^{\circ} \mathrm{C}$ temperature. Various growth parameters viz. microplant height, root length, no. of nodes, leaves and roots, fresh weight as well as dry weight was recorded after 21 days of incubation (Buckseth et al., 2017). In case of roots, as there was secondary branching, only primary roots were counted. Root length was recorded for the longest root in each plant. Fresh and dry weight was taken for all the three plantlets along with the root.

Micro-plants from each test tube were dried at $80^{\circ} \mathrm{C}$ for $48 \mathrm{~h}$ in the hot air oven and dry weight was recorded after bringing it to room temperature (Venkataslam et al., 2013). The experiment was conducted in a factorial $(2 \times 4 \times 5)$ completely randomized design. Each treatment comprised four replicates, each replicate consist of four test tubes having three plantlets. The three-way analysis of variance was done using the software AGRES and means were separated according to the least significant differences at 0.05 level of probability. 


\section{Results and Discussion}

Amphotericin-b at $0.5 \%$ and $1.0 \%$ significantly increased the microplants height as compared to control in Kufri Jyoti, K. Sindhuri, K. Lauvkar and Kufri Sadabahar respectively. Rest of the concentrations were at par with control (Table 1). However, Antimycotic at all concentrations retarded microplants height compared to control. In all the tested varieties i.e., K. Jyoti, K. Sindhuri, K. Lauvkar and K. Sadabahar, the no. of leaves were recorded more in each applied conc. of amphotericin-b as compared to control but the effect of different conc. was found to be statistically at par with each other. However, antimycotic at all concentrations decreased the no. of leaves in all tested varieties at all concentrations as compared to control (Table 1). Zhang et al., (1999) reported that at higher concentrations of antibiotic products so formed degrade the polyribosome that can inhibit protein synthesis and disrupt the membrane permeability.

In Kufri Lauvkar, amphotericin-b at 0.5\% conc. and $1.5 \%$ conc. in Kufri Sadabahar showed significant increase in no. of nodes/plantlet whereas; the effect of all the tested conc. was at par or slightly better than control. Antimycotic at all tested concentrations had negative effect on all the tested varieties for no. of nodes/plantlet. In Kufri Sadabahar, all the tested concentrations of amphotericin-b significantly increased the root no. compared to control whereas, in Kufri Sindhuri, higher conc. of amphotericin$b$ had positive effect on root number (Table 2). In Kufri Jyoti and Kufri Sindhuri, the root length was more in control. No positive effect of amphotericin-b was recorded. Amphotericin-b upto $1.5 \%$ conc. in Kufri Lauvkar showed increased in root length compared to control whereas, at all conc. it had positive effect on root length in Kufri
Sadabahar (Table 2). However, Antimycotic at all tested concentrations had negative effect on no. of roots and root length in all the tested varieties.

In Kufri Sadabahar, amphotericin-b at all concentrations significantly increased the fresh weight and dry weight as compared to control. The effects of all the tested concentrations were significant with each other (Table 3). In Kufri Jyoti, 0.5\% amphotericin-b had positive significant effect on fresh weight and dry weight as compared to control. All the tested concentrations of amphotericin-b were at par with control in Kufri Sindhuri and Kufri Lauvkar. Antimycotic irrespective of concentrations reduced the fresh weight and dry weight respectively.

Plant growth promoting effect of amphotericin-b upto certain concentrations may be responsible for its significant positive response on morphological characters of different varieties. Borrelli et al., (1992), Holford and Newbury (1992), Nakona and Mii (1993), Teng and Nicholson (1997), Venkataslam et al., (2013) have reported that in different crops morphogenetic response were promoted through the breakdown of the products formed by the metabolic activities of the cells during incubation period which mimic plant growth regulators. Negative effect of the tested concentrations of antimycotic on almost all the morphological characters of all the varieties as observed in the present investigation may be due to toxic effects of this antibiotic and such effects due to different antimicrobial agents have also been reported in Barley by Mathias and Mukasa (1987). The present study explains that the genotype is sole responsible to confer the microplants sensitivity as well as its tolerance limit to different antibiotic agents (Venkataslam et al., 2017; Buckseth et al., 2016). 
Table.1 Effect of antibiotics and their concentrations on microplant height and number of leaves

\begin{tabular}{|c|c|c|c|c|c|c|c|c|c|c|c|c|c|}
\hline \multirow[t]{2}{*}{ Variety } & \multirow[t]{2}{*}{ Antibiotics } & \multicolumn{8}{|c|}{ Microplant height } & \multicolumn{4}{|c|}{ Number of leaves } \\
\hline & & C1 & $\mathrm{C2}$ & $\mathbf{C 3}$ & $\mathrm{C4}$ & C5 & Mean & $\mathrm{C1}$ & $\mathrm{C2}$ & $\mathrm{C3}$ & $\mathrm{C4}$ & C5 & Mean \\
\hline \multirow[t]{4}{*}{ K. Jyoti } & Amphotericin & & 4.70 & 3.86 & 3.74 & 3.98 & & 2.12 & 2.46 & 2.48 & 2.40 & 2.64 & \\
\hline & & 3.60 & & & & & 3.92 & & & & & & 2.42 \\
\hline & Antimycotic & 3.60 & 2.74 & 1.62 & 1.12 & 1.12 & 2.04 & 2.12 & 2.28 & 1.46 & 1.12 & 1.40 & 1.68 \\
\hline & Mean & 3.60 & 3.72 & 2.59 & 2.43 & 2.55 & 2.98 & 2.12 & 2.37 & 1.97 & 1.76 & 2.02 & 2.05 \\
\hline \multirow[t]{3}{*}{ K. Sindhuri } & Amphotericin & 7.04 & 7.70 & 8.36 & 7.96 & 8.22 & 7.86 & 4.11 & 5.14 & 5.54 & 5.54 & 5.60 & 5.19 \\
\hline & Antimycotic & 7.04 & 6.94 & 5.06 & 5.36 & 4.84 & 5.85 & 4.11 & 4.98 & 4.40 & 4.00 & 4.08 & 4.31 \\
\hline & Mean & 7.04 & 7.32 & 6.71 & 6.66 & 6.53 & 6.85 & 4.11 & 5.06 & 4.97 & 4.77 & 4.84 & 4.75 \\
\hline \multirow[t]{3}{*}{ K. Lauvkar } & Amphotericin & 6.60 & 7.64 & 7.84 & 7.40 & 5.80 & 7.06 & 4.80 & 5.40 & 4.46 & 4.74 & 3.68 & 4.62 \\
\hline & Antimycotic & 6.60 & 4.78 & 3.02 & 2.82 & 2.40 & 3.92 & 4.80 & 3.34 & 2.40 & 2.02 & 2.26 & 2.96 \\
\hline & Mean & 6.60 & 6.21 & 5.43 & 5.11 & 4.10 & 5.49 & 4.80 & 4.37 & 3.43 & 3.38 & 2.97 & 3.79 \\
\hline \multirow[t]{4}{*}{ K. Sadabahar } & Amphotericin & 3.80 & 4.90 & 4.92 & 4.72 & 3.90 & 4.45 & 2.80 & 3.12 & 3.12 & 3.56 & 3.00 & 3.12 \\
\hline & Antimycotic & 3.80 & 3.06 & 2.20 & 1.50 & 0.84 & 2.28 & 2.80 & 2.26 & 2.02 & 1.74 & 1.26 & 2.02 \\
\hline & Mean & 3.80 & 3.98 & 3.56 & 3.11 & 2.37 & 3.36 & 2.80 & 2.69 & 2.57 & 2.65 & 2.13 & 2.57 \\
\hline & Grand Mean & 5.26 & 5.31 & 4.57 & 4.33 & 3.89 & & 3.46 & 3.62 & 3.23 & 3.14 & 2.99 & \\
\hline $\mathbf{V}$ & $\mathbf{A}$ & $\mathbf{C}$ & $\mathbf{V A}$ & $\mathbf{A C}$ & $\mathrm{VC}$ & VAC & $\mathbf{V}$ & $\mathbf{A}$ & $\mathbf{C}$ & VA & $\mathbf{A C}$ & $\mathrm{VC}$ & VAC \\
\hline SEd & 0.1 & 0.2 & 0.2 & 0.3 & 0.4 & 0.6 & 0.1 & 0.09 & 0.1 & 0.1 & 0.2 & 0.2 & 0.4 \\
\hline $\mathrm{CD}(0.05) \quad 0.3$ & 0.2 & 0.4 & 0.5 & 0.6 & NS & NS & 0.2 & 0.1 & 0.2 & 0.3 & 0.4 & 0.5 & NS \\
\hline
\end{tabular}

V: Variety; A: Antibiotics; C: Concentrations; Amphotericin (C1-Control, C2-0.5\%, C3-1.0\%, C4-1.5\% and C5-2.0\%); Antimycotic (C1-Control, C2-0.5\%, C3$1.0 \%, \mathrm{C} 4-1.5 \%$ and $\mathrm{C} 5-2.0 \%$ ) 
Table.2 Effect of antibiotics and their concentrations on number of nodes/plantlet, number of roots/plantlet and root length

\begin{tabular}{|c|c|c|c|c|c|c|c|c|c|c|c|c|c|c|c|c|c|c|c|c|c|c|c|c|}
\hline \multirow[t]{2}{*}{ Variety } & \multirow{2}{*}{\multicolumn{2}{|c|}{ Antibiotics }} & & \multicolumn{7}{|c|}{ Number of nodes/plantlet } & \multicolumn{7}{|c|}{ Number of roots/plantlet } & \multicolumn{7}{|c|}{ Root length } \\
\hline & & & & C1 & C2 & $\mathbf{C 3}$ & C4 & & C5 & Mean & $\mathbf{C 1}$ & $\mathrm{C2}$ & $\mathbf{C 3}$ & & $\mathrm{C4}$ & C5 & Mean & C1 & $\mathrm{C2}$ & C3 & & $\mathbf{C 4}$ & $\mathbf{C 5}$ & Mea \\
\hline \multirow[t]{3}{*}{ K. Jyoti } & Ampho & otericir & & 2.30 & 2.56 & 2.54 & 2.52 & & 2.74 & 2.53 & 8.54 & 8.86 & 7.46 & & 5.50 & 8.68 & 7.81 & 3.60 & 3.14 & 3.48 & & 2.54 & 2.88 & 3.13 \\
\hline & Antim & nycotic & & 2.30 & 2.28 & 1.46 & 1.18 & & 1.40 & 1.72 & 8.54 & 3.68 & 1.12 & & 0.01 & 0.01 & 2.67 & 3.60 & 2.24 & 0.24 & & 0.01 & 0.01 & 1.22 \\
\hline & $\mathrm{Me}$ & ean & & 2.30 & 2.42 & 2.00 & 1.85 & & 2.07 & 2.13 & 8.54 & 6.27 & 3.79 & & 2.75 & 4.34 & 5.14 & 3.60 & 2.69 & 1.86 & & 1.27 & 1.44 & 2.17 \\
\hline \multirow[t]{3}{*}{ K. Sindhuri } & Ampho & otericir & & 5.20 & 5.22 & 5.66 & 5.48 & & 5.86 & 5.48 & 6.11 & 5.60 & 5.86 & & 7.26 & 8.80 & 6.73 & 8.81 & 7.82 & 6.78 & & 7.34 & 8.54 & 7.86 \\
\hline & Antim & nycotic & & 5.20 & 4.44 & 3.94 & 3.78 & & 4.00 & 4.27 & 6.11 & 2.26 & 0.66 & & 0.32 & 0.06 & 1.88 & 8.81 & 3.58 & 1.22 & & 0.50 & 0.38 & 2.90 \\
\hline & $\mathrm{Me}$ & ean & & 5.20 & 4.83 & 4.80 & 4.63 & & 4.93 & 4.88 & 6.11 & 3.93 & 3.26 & & 3.79 & 4.50 & 4.32 & 8.81 & 5.70 & 4.00 & & 3.92 & 4.46 & 5.38 \\
\hline \multirow[t]{3}{*}{ K. Lauvkar } & Ampho & otericir & & 4.94 & 5.46 & 4.26 & 4.74 & & 3.66 & 4.61 & 7.02 & 7.60 & 8.26 & & 7.06 & 5.00 & 6.99 & 6.04 & 7.06 & 6.50 & & 6.10 & 5.40 & 6.22 \\
\hline & Antim & nycotic & & 4.94 & 3.54 & 1.94 & 2.00 & & 2.26 & 2.94 & 7.02 & 7.60 & 0.76 & & 0.88 & 0.06 & 3.26 & 6.04 & 3.78 & 2.90 & & 1.18 & 0.24 & 2.83 \\
\hline & $\mathrm{Me}$ & ean & & 4.94 & 4.50 & 3.10 & 3.37 & & 2.96 & 3.77 & 7.02 & 4.60 & 4.51 & & 3.97 & 2.53 & 4.53 & 6.04 & 5.42 & 4.70 & & 3.64 & 2.82 & 4.52 \\
\hline \multirow[t]{7}{*}{ K. Sadabahar } & Ampho & otericir & & 2.81 & 3.20 & 3.12 & 4.02 & & 3.08 & 3.25 & 6.26 & 9.76 & 8.18 & & 9.06 & 8.54 & 8.36 & 4.14 & 4.84 & 4.66 & & 4.42 & 4.44 & 4.50 \\
\hline & Antim & nycotic & & 2.81 & 2.26 & 2.02 & 1.74 & & 1.26 & 2.02 & 6.26 & 2.82 & 0.54 & & 0.52 & 0.20 & 2.07 & 4.14 & 3.06 & 0.80 & & 0.84 & 0.26 & 1.82 \\
\hline & $\mathrm{Me}$ & ean & & 2.81 & 2.73 & 2.57 & 2.88 & & 2.17 & 2.63 & 6.26 & 6.29 & 4.36 & & 4.79 & 4.37 & 5.21 & 4.14 & 3.95 & 2.73 & & 2.63 & 2.35 & 3.16 \\
\hline & Grand & Mean & & 3.81 & 3.62 & 3.12 & 3.18 & & 3.03 & & 6.98 & 5.27 & 3.98 & & 3.83 & 3.93 & & 5.65 & 4.44 & 3.32 & & 2.87 & 2.77 & \\
\hline & & $\mathbf{V}$ & $\mathbf{A}$ & $\mathbf{C}$ & VA & $\mathbf{A C}$ & $\mathrm{VC}$ & VAC & $\mathbf{V}$ & $\mathbf{A}$ & $\mathbf{C}$ & VA & $\mathbf{A C}$ & $\mathrm{VC}$ & VAC & $\mathbf{V}$ & $\mathbf{A}$ & $\mathbf{C}$ & VA & $\mathrm{AC}$ & $\mathrm{VC}$ & & & \\
\hline & SEd & 0.1 & 0.08 & 80.1 & 0.1 & 0.1 & 0.2 & 0.3 & 0.2 & 0.1 & 0.3 & 0.3 & 0.4 & 0.6 & 0.8 & 0.2 & 0.1 & 0.2 & 0.2 & 0.3 & 0.4 & & & \\
\hline & $\mathrm{CD}(0.05)$ & 0.2 & 0.1 & 0.2 & 0.3 & 0.3 & 0.5 & NS & 0.5 & 0.3 & 0.5 & 0.7 & 0.8 & 1.2 & 1.7 & 0.3 & 0.2 & 0.4 & 0.5 & 0.6 & 0.8 & & & \\
\hline
\end{tabular}

V: Variety; A: Antibiotics; C: Concentrations; Amphotericin (C1-Control, C2-0.5\%, C3-1.0\%, C4-1.5\% and C5-2.0\%); Antimycotic (C1-Control, C2-0.5\%, C3$1.0 \%, \mathrm{C} 4-1.5 \%$ and $\mathrm{C} 5-2.0 \%)$ 
Int.J.Curr.Microbiol.App.Sci (2017) 6(11): 956-963

Table.3 Effect of antibiotics and their concentrations on fresh weight (mg) and dry weight (mg)

\begin{tabular}{|c|c|c|c|c|c|c|c|c|c|c|c|c|c|c|}
\hline \multicolumn{2}{|c|}{ Variety } & \multicolumn{2}{|c|}{ Antibiotics } & \multicolumn{5}{|c|}{ Fresh weight } & \multicolumn{6}{|c|}{ Dry weight } \\
\hline & & & C1 & $\mathrm{C2}$ & $\mathrm{C3}$ & $\mathrm{C4}$ & C5 & Mean & C1 & $\mathrm{C2}$ & $\mathrm{C3}$ & $\mathrm{C4}$ & $\mathrm{C5}$ & Mean \\
\hline \multirow{3}{*}{\multicolumn{2}{|c|}{ K. Jyoti }} & Amphotericin & 206.78 & 251.16 & 188.46 & 203.0 & 221.76 & 214.23 & 11.98 & 15.14 & 14.82 & 10.76 & 13.58 & 13.26 \\
\hline & & Antimycotic & 206.78 & 142.90 & 100.02 & 104.62 & 97.44 & 130.35 & 11.98 & 10.96 & 11.10 & 10.36 & 8.80 & 10.64 \\
\hline & & Mean & 206.78 & 197.03 & 144.24 & 153.81 & 159.60 & 172.29 & 11.98 & 13.05 & 12.96 & 10.56 & 11.19 & 11.95 \\
\hline \multirow{3}{*}{\multicolumn{2}{|c|}{ K. Sindhuri }} & Amphotericin & 241.40 & 224.06 & 161.68 & 180.90 & 252.46 & 212.10 & 19.72 & 15.70 & 11.42 & 11.90 & 17.48 & 15.02 \\
\hline & & Antimycotic & 241.40 & 145.80 & 95.00 & 89.18 & 76.76 & 129.63 & 19.72 & 13.44 & 10.70 & 8.46 & 7.94 & 12.05 \\
\hline & & Mean & 241.40 & 184.93 & 128.34 & 135.04 & 164.61 & 170.86 & 19.72 & 14.57 & 11.06 & 10.18 & 12.71 & 13.65 \\
\hline \multirow{3}{*}{\multicolumn{2}{|c|}{ K. Lauvkar }} & Amphotericin & 189.64 & 186.56 & 175.84 & 229.12 & 161.64 & 188.56 & 10.02 & 10.74 & 10.12 & 11.96 & 12.04 & 10.98 \\
\hline & & Antimycotic & 189.64 & 137.62 & 88.84 & 116.38 & 97.36 & 125.97 & 10.02 & 9.94 & 9.34 & 7.38 & 9.24 & 9.18 \\
\hline & & Mean & 189.64 & 162.09 & 132.34 & 172.75 & 129.50 & 157.26 & 10.02 & 10.34 & 9.73 & 9.67 & 10.64 & 10.08 \\
\hline \multirow{4}{*}{\multicolumn{2}{|c|}{ K.Sadabahar }} & Amphotericin & 285.76 & 386.22 & 377.08 & 410.40 & 378.68 & 367.63 & 18.44 & 21.64 & 19.88 & 25.36 & 23.78 & 21.82 \\
\hline & & Antimycotic & 285.76 & 185.58 & 142.58 & 121.80 & 112.96 & 169.74 & 18.44 & 16.42 & 15.60 & 15.62 & 13.06 & 15.83 \\
\hline & & Mean & 285.76 & 285.90 & 259.83 & 266.10 & 245.82 & 268.68 & 18.44 & 19.03 & 17.74 & 20.49 & 18.42 & 18.82 \\
\hline & & Grand Mean & 230.90 & 207.49 & 166.19 & 181.93 & 174.88 & & 15.04 & 14.25 & 12.87 & 12.73 & 13.24 & \\
\hline & $\mathbf{V}$ & $\mathbf{A}$ & C & VA & $\mathbf{A C}$ & VC & VAC & $\mathbf{V}$ & $\mathbf{A}$ & C & VA & $\mathbf{A C}$ & VC & VAC \\
\hline SEd & 9.2 & 6.5 & 10.3 & 13.1 & 14.6 & 20.7 & 29.3 & 0.6 & 0.4 & 0.7 & 0.9 & 1.1 & 1.5 & 2.2 \\
\hline $\mathrm{CD}(0.05)$ & 18.3 & 12.9 & 20.4 & 25.9 & 28.9 & 40.9 & NS & 1.3 & 0.9 & 1.5 & 1.9 & NS & 3.0 & 4.3 \\
\hline
\end{tabular}

V: Variety; A: Antibiotics; C: Concentrations; Amphotericin (C1-Control, C2-0.5\%, C3-1.0\%, C4-1.5\% and C5-2.0\%); Antimycotic (C1-Control, C2-0.5\%, C3$1.0 \%, \mathrm{C} 4-1.5 \%$ and $\mathrm{C} 5-2.0 \%$ ) 
Therefore, it is considered of utmost importance that the use of antibiotics is done in a controlled manner, (both choice and concentrations) in order to maintain the endophytes / microplanta balance.

Amphotericin-b can be incorporated in the micro propagation medium of potato to minimize fungal contaminations as well as for improving the microplants vigour. However, all the antimycotic concentrations had negative effects on almost all the morphological characters studied and this might be toxicity of the concentrations used, which needs further investigation with lower concentrations. Thus, there is remote chance to use this antibiotic at the present test dose.

\section{Acknowledgements}

The authors are grateful to the Indian Council of Agricultural Research, New Delhi, India for providing financial supports and necessary facilities to carry out research work.

\section{References}

Borelli, G.M., Difonzo, N. and Lupotto, E. 1992. Effect of cephotoxime on callus culture and plant regeneration in durum wheat. J. Plant Physiol. 140, 372-74.

Buckseth Tanuja, RK Singh, Sumita Sharma, Ashwani K Sharma, Chakrabarti, SK 2017. Training cum laboratory manual on hi-tech seed potato production. ICAR-Central Potato Research Institute, Shimla, Himachal Pradesh, India. Extension bulletin 104, 46 p.

Buckseth Tanuja, Sharma, A.K., Pandey, K.K., Singh, B.P. and R. Muthuraj 2016. Methods of pre-basic seed potato production with special reference to aeroponics - a review, Scientia Horticulture, 204, 79-87.

George, E.F. 1993. Plant propagation by tissue culture. Exergetics Ltd.,
Edington, England: 574p.

Harshal, A., Bhoite and Gautam, S. Palshikar. 2014. Plant Tissue Culture: A Review. World Journal of Pharmaceutical Sciences. 2(6), 565-572.

Holfard, P. and Newbury, H.J. 1992. The effect of antibiotics and their break down products on the in vitro growth of Antirrhinum majus. Plant Cell Rep. 11, 93-96.

Jung, V. 2003. The role of selected plant and microbial metabolites in the nutrient solution of closed growing systems in greenhouses. Swedish University of Agricultural Science. Dissertation, Agraria: 418p.

Leifert, C. 2000. Quality Assurance systems for plant cell and tissue culture, the problem of latent persistence of bacterial pathogens and Agrobacterium - based transformation vector systems. Acta Hort. 530, 87-91.

Leifert, C. and Waites, W.M. 1992. Bacterial growth in plant tissue culture media. $J$. Appl. Bacteriol. 72, 460-466.

Leifert, C., Cassells, A. 2001. Microbial hazards in plant tissue and cell cultures. In Vitro Cellular \& Developmental Biology. 37, 133-138.

Mathias, R.J. and Mukasa, C. 1987. The effect of cefotaxime on the growth and regeneration of callus from varieties of barley (Hordeum vulgare L.). Plant Cell Rep. 6, 454-57.

Murashige, T. and F., Skoog. 1962. A revised medium for rapid growth and bioassays with tobacco tissue cultures. Physiol. Plantarum. 15, 473-497.

Naik, P.S. and Karihaloo, J.L. 2007 Micropropagation for Production of Quality Potato Seed in Asia-Pacific. Asia-Pacific Consortium on Agricultural Biotechnology (APCoAB), New Delhi, India 54p.

Nakona, M. and Mii, M. 1993. Antibiotics stimulate embryogenesis with plant 
growth regulators in several Dianthus cultivars. J. Plant Physiol. 141, 721-25.

Sen, M.K., Hassan, M.M., Nasrin, S., Jamal, M.A.H.M., Mamun-Or-Rashid, A.N.M. and Dash, B.K. 2013. In vitro sterilization protocol for micropropagation of Achyranthes aspera L. node. Int. Res. J. Biotechnology. 4, 89-93.

Singh, R.K., S.K. Dubey, Rakesh, K. Singh, S.N. Singh, Tanuja Buckseth and A.K. Singh. 2016. Farmer participatory seed potato Production through Krishi Vigyan Kendra networking: an action research for enhanced availability of seed Potatoes in India. Potato J. 43(2), 193-199.

Teng, W.L. and Nicholson, L. 1997. Pulse treatment of penicillin-G and streptomycine minimize internal infections and has post treatment effects on the morphogenesis of ginseng root culture. Plant Cell Rep. 16, 531-35.

Venkatasalam, E.P., K.K. Pandey, B.P. Singh, Vandana Thakur, Shilpa Sharma, Richa Sood and Ashwani K. Sharma. 2013. Efficacy of antimicrobial agents on in vitro micropropagation potential of potato. Potato J. 40 (1), 45-54.

Venkataslam, E.P., R. K. Singh, Ashwani K. Sharma, Vinay Singh, Tanuja Buckseth, S.K. Chakrabarti. 2017. Seed Potato Production Techniques: Principles and Applications. ICAR-Central Potato Research Institute, Shimla. Extension bulletin 105, 101p.

Zhang, Q., Wiskich, J.T. and Woole, K, I. 1999. Respiratory activities in chlorophenicaol- treated tobacco cells. Physiol Plantarum. 105, 224-32.

\section{How to cite this article:}

Tanuja Buckseth, R.K. Singh, Sumita Sharma, Ashwani K. Sharma, Vaishali Moudgil and Aastha Saraswati. 2017. Antibiotics Efficacy on In Vitro Growth Parameters of Important Potato Cultivars. Int.J.Curr.Microbiol.App.Sci. 6(11): 956-963. doi: https://doi.org/10.20546/ijcmas.2017.611.112 